\title{
Brexit's Hidden Costs for Britons Living in the EU
}

\author{
Michaela BENSON
}

I $\mathrm{n}$ recent months, the formal Brexit transition period has come to an end, completing Britain's exit from the European Union. Delivering on the Leave Campaign's promise to end unrestricted immigration to the United Kingdom from Europe has resulted in shutting British citizens out of the EU's free movement regime. The cost of Brexit for each and every British citizen has been the automatic loss of the EU citizenship that came with Britain's membership in the EU. While this has indirect repercussions for all British citizens, the consequences were more immediate for the estimated 1.2 million Britons who had taken up the opportunities offered by the project of European integration and settled elsewhere in the EU. Yet the British in Europe are a lesser known story of these times.

Brexit is part of the long-standing politicization of migration in Britain. Most recently, this took shape as the "hostile environment" policies of successive Conservative-led governments since 2010. Over this period, officials sought public support for an increasingly restrictive and exclusionary immigration regime, reframing the question of who should have the right to settle in the UK around a distinction between deserving and undeserving migrants.

The Leave Campaign piggybacked on this narrative, casting Europe as a threat to Britain's sovereignty over its own borders. Central within this framing was the misrepresentation of free movement—of EU citizens, alongside goods and services originating in the EU-as a system of open borders that anyone could cross. The pro-Brexit camp promoted the idea that this system had left Britain and its welfare state vulnerable to abuse by benefitscrounging Europeans. The only solution was to shut the border and put an end to free movement.

MiCHAELA BENSON is a reader in sociology at Goldsmiths, University of London.
This rhetoric lacked supporting evidence, but nevertheless proved potent. On June 23, 2016, a narrow majority of British voters approved the proposal for Britain to exit the EU, setting in motion a withdrawal process that would last more than four years.

\section{A DIVERSE AND DISPERSED DIASPORA}

The Brexit story's neglect of 1.2 million British citizens living in the EU is perhaps unsurprising when placed in the broader context of Britain's self-image as an "island nation" whose recent approach to migration lies in ensuring that it has strong borders. Yet emigration has long played an important role in Britain's real migration story.

Following the long history of people leaving Britain to take part in the formation of the British Empire, the scale of contemporary emigration flows has made Britain's emigrant population one of the largest in the world. Over the past forty years, mobility within the EU has become an important part of that story. In the first decade of the twenty-first century, greater numbers of British citizens left the UK for the EU than for destinations in the former British dominions of Australia, New Zealand, and Canada. Free movement was two-way traffic.

British citizens in the EU are one of the success stories of Europeanization. They are often economically and socially integrated in their places of work and residence. A broad-brush understanding of what inspired their mobility within the EU includes opportunities for work, study, and retirement, but also love: dual-national relationships are a common illustration of the intimate life changes wrought through Europeanization.

Although popular representations of the British on the continent all too often fixate on those who have retired to the sunnier climes of southern Europe, the emigré population is as diverse as the British population as a whole. At least 75 percent of Britons living in the EU are of working age and 
below. They include people of color, as well as children born and educated in the EU. For some, mobility within Europe has been tied to social mobility, particularly at times when opportunities were more restricted in Britain. As a result of the lower thresholds for settlement available to EU citizens, British citizens occupy all the different strata of European and local labor markets, from seasonal work in the tourism and hospitality sectors to managerial roles in European and multinational companies.

UK citizens have settled in all 27 EU member states, with substantial British populations found in Spain, France, and Ireland. Once they are socially integrated, they may or may not seek out social relationships with other British citizens. In fact, at the time of the Brexit referendum, their most notable characteristic was how seldom they had formed extensive networks with their compatriots in Europe, beyond the support groups that had developed on the ground within identifiable British communities in Europe. Brexit would change that.

\section{SHRINKING RIGHTS}

As the referendum approached, British citizens who had lived outside the UK for longer than fifteen years discovered that they would not be able to vote. Although Leave campaigners promised that nothing would change for them or for the 3 million EU citizens living in the UK, this turned out to be little more than an empty promise. Once Article 50 of the EU's Lisbon Treaty was triggered, signaling Britain's intention to leave the EU, the terms for the exit negotiations made it clear that new legislation and processes would be needed to protect the rights of these mobile citizens in the post-Brexit era. Although citizens' rights were at the heart of phase one of the talks, the negotiating guidelines issued by the European Council made clear that "nothing is agreed until everything is agreed."

As the negotiations dragged on, deadlines were extended time and again. The threat of the talks collapsing and Britain leaving without a deal repeatedly raised its head. Even after the Withdrawal Agreement was struck, and endorsed by the European Council in late 2018, political turbulence in the UK prevented passage of the pact by Parliament. It was only at the eleventh hour, just before the Brexit deadline, that it became law in January 2020. This finally secured the limited accommodations and protections the Withdrawal Agreement offered to British citizens who had lawfully exercised their right to free movement.
Now that they are no longer EU citizens with conditional rights to free movement, their new status is only a shadow of what they had enjoyed previously. Although the agreement secures the necessary legal basis of their residency in Europe, with access to the labor market, health care, and social security, it shrinks the geographical scope of their rights and entitlements to their country of residence. As such, they are no longer eligible for continued freedom of movement within the $\mathrm{EU}$ and lose their franchise in European Parliament elections. But they will still have more expansive rights than British citizens moving to the EU after Brexit.

In light of this narrowing geographical scope of rights, implementation of the Withdrawal Agreement was left to individual member states. First held up by the prolongation of the Brexit negotiations, the process was further delayed by the COVID-19 pandemic.

These are the headlines of what Brexit means, at a political and legal level, for British citizens already living within the EU. But it doesn't end there.

\section{CAUGHT IN THE CROSSHAIRS}

Since the Brexit referendum, the lives of these Britons in Europe have been caught in the crosshairs of the tense negotiations between the UK and the EU, as well as the British government's internal political wrangling over how hard a line to take on Brexit. Even in late 2020, with the end of the Brexit transition period fast approaching, many EU member states still had not released the final details of the domestic legislation, processes, and systems they would need to adopt so that British citizens lawfully residing within their borders could secure their rights under the terms of the Withdrawal Agreement.

And with no answers, there was nowhere to turn. Information provided by the UK government or EU member states was limited and slow to trickle down, giving British citizens in Europe the impression that they were out of sight and out of mind. Many have experienced a sense of profound uncertainty and helplessness.

Nonetheless, Britons started to take matters into their own hands the morning after the referendum. For some, this meant political organizing, as new grassroots organizations advocating for the rights of British citizens living in the EU quickly gained momentum. Others started to explore what was within their power as individuals to limit the 
already tangible effects of Brexit on their lives. Aware that Britain's withdrawal was already destabilizing the foundations of their mobility and settlement within the EU, they sought to establish new roots.

For many of these Britons living in the EU, establishing new roots meant formalizing their residence status. In countries with no compulsory requirement for EU citizens to register their residency (such as France), this resulted in an unprecedented surge in applications and an associated administrative burden for municipal officers tasked with processing them. Some British citizens reported that they had been sent away emptyhanded on various grounds-that as EU citizens they did not need these permits, that they were not eligible because of Brexit, or that the permits would not be valid after Brexit. It was clear that local municipal officers were flummoxed about the status of British citizens following the Brexit referendum.

For others who had deferred making a firm commitment to residence in a particular member state as long as they had the ability to move with ease across the EU, Brexit forced a reassessment. It became clear that lawful residence would be the measure of whether they were covered by the terms of the Withdrawal Agreement. They made decisions about their future residence plans that they had been putting off.

EU member states permitting dual nationality saw large increases in the numbers of resident British citizens applying for citizenship. Another route was for Britons to claim citizenships to which they were entitled through ancestry (as in Ireland) as a way of maintaining their rights as EU citizens. But the pursuit of citizenship was considerably more restrained in countries with an official requirement for new citizens to renounce any other nationality upon naturalization (as in Spain).

Not everyone had access to such preemptive strategies. Contrary to the Leave Campaign's mischaracterization of Europeans moving to the UK to take advantage of the welfare state, freedom of movement was always a conditional right. In some cases, British citizens spurred to register their residence abroad found themselves judged against conditional requirements, compelled to demonstrate that they were not a burden to the nation-state and had the Comprehensive Sickness Insurance required by EU law.

In a handful of cases in France, it was determined that British citizens were not lawful residents, sometimes after they had lived there for many years. They simply lacked sufficient resources to sustain themselves, due to factors such as chronic ill health restricting the ability to continue working, or a recent bereavement resulting in a serious loss of income.

A ruling that someone is not lawfully resident can cut off their access to health care and other social entitlements; if these decisions are not overturned, it might also mean that they are not eligible for the protections provided by the Withdrawal Agreement. The administrative burden and associated costs of applying for citizenship could place secure status further out of reach for some of these Britons. After many years of working with British citizens living in France, it would not surprise me to see those who are most vulnerable, living in relative poverty but able to survive hand to mouth in part because of a low cost of living, choose to continue to live undocumented lives.

The impact of Brexit has already been unevenly felt among British citizens living in the EU. Their different social positions along intersecting axes-including class, gender, race, age, and disability-left them vulnerable to Brexit in a variety of ways and positioned them to respond differently to its effects on their lives. As the Withdrawal Agreement is implemented and they come to rely on its protections, it is likely that these inequalities will become even more visible.

The focus of the Leave Campaign on the politics of immigration downplayed and overlooked the presence of British citizens living in the EU. Although they are only one part of a bigger picture, they have had to find ways of living with the direct consequences of Britain's vote to leave the EU. As the transition period ends, their new status will come into force. In the months, years, and decades to come, the Withdrawal Agreement and the protections it offers these former EU citizens will be put to the test. Only time will tell if it is up to the task. 